\title{
Integrasi Pendidikan Karakter Melalui Pendekatan Kontekstual Dalam Mata Kuliah Profesi Pendidikan Terhadap IQ Dengan Mengendalikan EQ dan SQ Mahasiswa
}

\author{
Theodora Sarlotha Nirmala Manu, Agus Maramba Meha \\ piva_mn@yahoo.com, agusmaramba@yahoo.com \\ FKIP Pendidikan Biologi, Universitas Kristen Artha Wacana Kupang
}

\author{
The Effect Of Self Confidence Towards Students'Motivation For Achievements In Science Lesson
}

\begin{abstract}
This research aims to examine whether there is an influence of self-confidence in students' motivation to achievement in science lesson in elementary schools. This is a field research, where the researchers are involved directly down to the place of research to collect the data relevant to the indicators in the research objectives, which classifies this as a field research with a correlational quantitative approach. Correlational quantitative research is research to determine the level of relations between two or more variables, without making changes, additions, or manipulations of data that already exists. The data analysis techniques was done by observations and questionnaires instruments. Based on the results of analysis with manual calculations, the R Square correlation coefficient is 0.39 or $39 \%$ which means that selfconfidence affects student motivation for achievement, while the rest is influenced by other variables of $61 \%$ that were not examined. This indicates that the variations of confidence with motivation of achievement is $39 \%$. Based on the calculation, the tcount valued $2.898>$ from $t_{\text {table, }}$ with $d k=48$, worth 2.011 which means there is an influence of confidence $(X)$ to motivation for achievement $(Y)$. The hypothesis for Ha is accepted and Ho is rejected.
\end{abstract}

Keywords: Self Confidence, Motivation, Student Achievements, Science Lesson

\section{Article Info}

Received date: 10 April 2019

Revised date: 21 Agustus 2019

Accepted date: 19 September 2019

\section{PENDAHULUAN}

Menurut Kemendiknas (2010) sebagaimana disebutkan dalam buku induk kebijakan Nasional pembangunan karakter bangsa mulai tahun 2010, pemerintah mencanangkan penerapan pendidikan karakter bagi semua tingkat pendidikan, dari tingkat sekolah dasar sampai tingkat perguruan tinggi. Visi penerapan pendidikan karakter mendasari pelaksanaan pendidikan untuk menghasilkan generasi yang cerdas dan memiliki karakter yang kuat dalam membangun bangsa. Lembaga-lembaga pendidikan formal mulai dari tingkat pendidikan dasar sampai pada lembaga di perguruan tinggi memiliki tugas dan tanggung jawab untuk menjalankan maksud tersebut.

Karakter menurut Aunillah (2011) mengacu pada serangkaian sikap (attitudes), perilaku (behaviors), motivasi (motivations) dan keterampilan (skills). Perguruan tinggi sebagai lembaga pendidikan formal perlu memberikan pendidikan yang membentuk karakter mahasiswa, menggugah, mendorong, dan memudahkan mahasiswa untuk mengembangkan kebiasaan baik. Kebiasaan itu tumbuh dan berkembang dengan didasari oleh kesadaran, keyakinan, kepekaan, dan sikap. Karakter dapat berkembang menjadi kebiasaan baik karena adanya dorongan dari dalam, bukan paksaan dari luar.

Perguruan tinggi khususnya Lembaga Pendidikan Tenaga Kependidikan (LPTK) yang diberi kewenangan sebagai penyelenggara pendidikan profesi bagi guru harus merancang pembelajaran secara terintegrasi agar dapat menghasilkan guru yang profesional, berkarakter unggul dan terpuji yang dapat dijadikan teladan di masyarakat (Aisyah, 2014). Program Studi Pendidikan Biologi (PSPB) sebagai salah satu program studi yang berada di bawah Fakultas Keguruan dan Ilmu Pendidikan (FKIP) sebagai 
LPTK yang menghasilkan calon guru dituntut menghasilkan sumber daya yang berkualitas dan memiliki nilai karakter yang kuat untuk pembangunan bangsa Indonesia ke depan.

Mata kuliah profesi merupakan mata kuliah yang berada dalam kelompok Mata Kuliah Keilmuan dan Keterampilan (MKKK) bertujuan untuk membekali mahasiswa dengan pengetahuan/wawasan dan pemahaman terhadap berbagai konsep dan teori tentang profesi pendidikan dan kemampuan untuk menganalisis berbagai masalah pendidikan serta terampil mengaplikasikannya sebagai calon tenaga kependidikan dalam bidang pembelajaran Biologi.

Berdasarkan hasil wawancara, proses penyelenggaraan perkuliahan profesi pendidikan pada PSPB UKAW selama ini masih menggunakan pendekatan-pendekatan pembelajaran yang berpusat pada ketercapaian aspek kognitif (pengetahuan) yang diberikan kepada mahasiswa. Pelaksanaan pembelajaran yang menanamkan dan membentuk nilai-nilai karakter melalui integrasi pendidikan karakter dan pendekatan kontekstual belum dilakukan dalam proses perkuliahan. Kurang maksimalnya penyelenggaraan pembelajaran dengan integrasi pendidikan karakter melalui mata kuliah Profesi Pendidikan menyebabkan mahasiswa hanya memiliki kemampuan dalam hal pengetahuan (cognitive). Kegiatan pembelajaran pada mata kuliah tersebut pada umumnya belum secara memadai mendorong terinternalisasinya kecerdasan intelektual, kecerdasan emosional dan kecerdasan spiritual mahasiswa.

Pemilihan pendekatan kontekstual diintegrasikan dengan pendidikan karakter karena dapat memfasilitasi mahasiswa untuk meningkatkan kecerdasan intelektual (IQ), kecerdasan emosional (EQ) dan kecerdasan spiritual (SQ). Prinsip-prinsip pendekatan kontekstual diintegrasi pendidikan karakter seperti prinsip konstruktivisme, bertanya, inkuiri, masyarakat belajar, pemodelan, refleksi, penilaian autentik, dan penanaman nilai karakter mahasisiwa dapat mengembangkan kecerdasan IQ,EQ,dan SQ mahasiswa.

Tikollah dkk (2006) menyatakan bahwa IQ, EQ, dan SQ tak terpisahkan dalam kehidupan seseorang, oleh karena itu dalam upaya pembentukan dan pengembangan sikap maka ketiga kecerdasan tersebut saling melengkapi. Kecerdasan tidak dapat dipisahkan dari ilmu karena orang yang cerdas biasanya adalah orang yang berilmu, demikian juga orang yang berilmu akan menjadi orang yang cerdas. Orang yang mempunyai kecerdasan, baik itu IQ maupun EQ akan kurang sempurna bila tidak mempunyai kecedasan SQ. Jadi seharusnya IQ, EQ dan SQ pada diri setiap orang mampu secara proporsional bersinergi, menghasilkan kekuatan untuk mencapai keseimbangan.

Terkait dengan hal di atas, maka diperlukan integrasi pendidikan karakter melalui pendekatan kontekstual dalam mata kuliah profesi pendidikan..

\section{KAJIAN PUSTAKA}

\section{Pengertian Pendidikan Karakter}

Menurut Kemendiknas (2011), pendidikan karakter adalah usaha menanamkan kebiasaankebiasaan yang baik (habituation) sehingga peserta didik mampu bersikap dan bertindak bersadarkan nilai-nilai yang telah menjadi kepribadiannya. Lain halnya dengan Aunillah (2011) seseorang yang dianggap memiliki karakter (mulia) dalam sikap dan tingkah lakunya, apabila seseorang yang mempunyai pengetahuan serta mampu mewujudkan potensi itu, adapun ciri-cirinya mampu memanfaatkan potensi dirinya, terpupuknya sikap terpuji, seperti penuh refleksi, percaya diri, rasional, logis, kritis, analitis, kreatif, inovatif, mandiri, hidup sehat, bertanggung jawab, cinta ilmu, sabar, berhati-hati, rela berkorban, berani, dapat dipercaya,, tekun, ulet, gigih, teliti, berinisiatif, berpikir positif, disiplin, antisipatif, inisiatif, visioner, bersahaja, bersemangat, dinamis, hemat, efisien, menghargai waktu, penuh pengabdian berhati lembut, setia, bekerja keras, jujur, menepati janji, adil, rendah hati, malu berbuat salah, pemaaf, dedikatif, mampu mengendalikan diri, produktif, ramah, cinta keindahan, sportif, tabah, terbuka dan tertib.

Dengan demikian para peserta didik yang disebut berkarakter baik atau unggul adalah mereka yang selalu berusaha melakukan hal-hal yang terbaik terhadap Tuhan Yang Maha Esa, diri sendiri, sesama manusia, lingkungan, negara, bangsa dan masyarakat dunia internasional pada umumnya dengan mengoptimalkan potensi dirinya disertai dengan kesadaran emosi dan motivasi yang tinggi.

\section{Integrasi Pendidikan Karakter Dalam Pembelajaran}

Pendidikan karakter di perguruan tinggi bertujuan untuk meningkatkan mutu penyelenggaraan dan hasil pendidikan yang mengarah pada pencapaian pembentukan karakter dan akhlak mulia peserta didik secara utuh, terpadu, dan seimbang, sesuai standar kompetensi lulusan. Melalui pendidikan 
karakter diharapkan mahasiswa mampu secara mandiri meningkatkan dan menggunakan pengetahuannya, mengkaji dan menginternalisasi nilai-nilai karakter dan akhlak mulia sehingga terwujud dalam perilaku sehari-hari.

Dalam Pusat Kurikulum Depdiknas (2010), dinyatakan bahwa pendidikan karakter berfungsi: (1) mengembangkan potensi dasar agar berhati baik, dan berperilaku baik; (2) memperkuat dan membangun perilaku bangsa yang multikultur; (3) meningkatkan peradaban bangsa yang kompetitif dalam pergaulan dunia.

Nilai pendidikan karakter dalam Pusat Kurikulum Depdiknas (2010) dapat diuraikan menjadi 18 butir, seperti berikut: (1) Religius, merupakan suatu sikap dan perilaku yang patuh dalam melaksanakan ajaran agama yang dianutnya, toleran terhadap pelaksanaan ibadah agama lain, serta hidup rukun dengan pemeluk agama lain; (2) Jujur, adalah perilaku yang didasarkan pada kebenaran, menghindari perilaku yang salah, serta menjadikan dirinya menjadi orang yang selalu dipercaya dalam perkataan, tindakan, dan pekerjaan; (3) Toleransi, suatu tindakan dan sikap yang menghargai pendapat, sikap dan tindakan orang lain yang berbeda pendapat, sikap, dan tindakan dengan dirinya; (4) Disiplin, suatu tindakan tertib dan patuh pada berbagai ketentuan dan peraturan yang harus dilaksanakannya; (5) Kerja keras, suatu upaya yang diperlihatkan untuk selalu menggunakan waktu yang tersedia untuk suatu pekerjaan dengan sebaik-baiknya sehingga pekerjaan yang dilakukan selesai tepat waktu; (6) Kreatif, berpikir untuk menghasilkan suatu cara atau produk baru dari apa yang telah dimilikinya; (7) Mandiri, kemampuan melakukan pekerjaan sendiri dengan kemampuan yang telah dimilikinya; (8) Demokratis, sikap dan tindakan yang menilai tinggi hak dan kewajiban dirinya dan orang lain dalam kedudukan yang sama; (9) Rasa ingin tahu, suatu sikap dan tindakan yang selalu berupaya untuk mengetahui apa yang dipelajarinya secara lebih mendalam dan meluas dalam berbagai aspek terkait; (10) Semangat kebangsaan,suatu cara berfikir, bertindak, dan wawasan yang menempatkan kepentingan bangsa dan negara di atas kepentingan diri dan kelompoknya; (11) Cinta tanah air,suatu sikap yang menunjukkan kesetiaan, kepedulian dan penghargaan yang tinggi terhadap lingkungan fisik, sosial, budaya, ekonomi dan politik bangsanya; (12) Menghargai prestasi, suatu sikap dan tindakan yang mendorong dirinya untuk menghasilkan sesuatu yang berguna bagi masyarakat dan mengakui serta menghormati keberhasilan orang lain. (13) Bersahabat/komunikatif, suatu tindakan yang memperlihatkan rasa senang berbicara, bergaul dan bekerjasama dengan orang lain; (14) Cinta damai, suatu sikap dan tindakan yang selalu menyebabkan orang lain senang dan dirinya diterima dengan baik oleh orang lain, masyarakat dan bangsa; (15) Senang membaca, suatu kebiasaan yang selalu menyediakan waktu untuk membaca bahan bacaan yang memberikan kebajikan bagi dirinya; (16) Peduli sosial, suatu sikap dan tindakan yang selalu ingin memberikan bantuan untuk membantu orang lain dan masyarakat dalam meringankan kesulitan yang mereka hadapi. (17) Peduli lingkungan, suatu sikap dan tindakan yang selalu berupaya mencegah kerusakan pada lingkungan alam di sekitarnya dan mengembangkan upayaupaya untuk memperbaiki kerusakan alam yang sudah terjadi; (18) Tanggung jawab, sikap dan perilaku seseorang untuk melaksanakan tugas dan kewajiban yang seharusnya dilakukan terhadap diri sendiri, masyarakat, lingkungan (alam, sosial dan budaya), negara dan Tuhan Yang Maha Esa.

Marten (2004) mengusulkan strategi pembelajaran karakter yang efektif, yakni secara lebih konkrit. Ada tiga tahapan yang perlu dilakukan dalam pembelajaran karakter, yakni: 1) identifikasi nilai, 2) pembelajaran nilai, dan 3) memberikan kesempatan untuk menerapkan nilai tersebut.

Identifikasi Nilai terkait dengan nilai-nilai moral apa saja yang sekurang- kurangnya harus dimiliki oleh individu. Dalam realitas kehidupan, ada sejumlah nilai yang terkonstruksi di dalam masyarakat, yang sangat boleh jadi antara masyarakat yang satu dengan yang lain berbeda.

Pembelajaran Nilai, temukan nilai moral yang ditargetkan, nilai moral tersebut selanjutnya ditanamkan kepada mahasiswa melalui langkah-langkah sebagai berikut: (a) Menciptakan lingkungan yang memungkinkan nilai-nilai moral tersebut diterapkan (b) Adanya keteladanan atau model perilaku moral. Menunjukkan perilaku bermoral memiliki dampak yang lebih kuat daripada berkata-kata tentang moral. (c) Menyusun aturan atau kode etik berperilaku baik. Mahasiswa perlu mengetahui apa yang boleh dilakukan dan apa yang tidak boleh dilakukan. Artinya, ada pemahaman yang sama terkait dengan perilaku moral. (d) Menjelaskan dan mendiskusikan perilaku bermoral. Ketika usia anak-anak, belajar perilaku moral dilakukan dengan cara imitasi dan praktik tanpa harus mengetahui alasan mengapa hal itu dilakukan atau tidak dilakukan. Memasuki usia remaja dan dewasa, kemampuan bernalarnya telah berkembang. Karena itu, perlu ada penjelasan dan bila perlu ada proses diskusi untuk sampai pada pilihan perilaku moral yang diharapkan. (e) Menggunakan dan mengajarkan etika dalam pengambilan 
keputusan. Individu acapkali dihadapkan pada pilihan-pilihan yang harus diambil keputusannya. Mengambil keputusan adalah proses mengevaluasi tindakan-tindakan dan memilih alternatif tindakan yang sejalan dengan nilai moral tertentu. (f) Mendorong individu mahasiswa mengembangkan nilai yang baik.

Tahap ketiga yang perlu dilakukan adalah memberikan kesempatan untuk mengaplikasikannya. Hal terpenting bertalian dengan penerapan nilai adalah konsistensi antara apa yang diajarkan dengan apa yang diterapkan. Artinya, apa yang dikatakan harus berbanding lurus dengan apa yang dilakukan, baik pada lingkungan kampus maupun dalam keluarga dan masyarakat..

\section{Pengertian Pendekatan Kontekstual}

Pembelajaran kontekstual (contextual teaching and learning) merupakan konsep belajar yang dapat membantu guru mengaitkan antara materi yang diajarkannya sebagai situasi dunia nyata siswa dan mendorong siswa membuat hubungan antara pengetahuan yang dimilikinya dengan penerapan dalam kehidupan mereka sebagai anggota keluarga dan masyarakat (Rusman, 2012).

Pembelajaran kontekstual adalah pembelajaran yang memungkinkan terjadinya proses belajar dimana siswa menggunakan pemahaman dan kemampuan akademiknya dalam berbagai konteks dalam dan luar sekolah untuk memecahkan masalah yang bersifat simulatif ataupun nyata, baik sendiri-sendiri maupun bersama-sama.

\section{Prinsip Pembelajaran Kontekstual}

Ada tujuh prinsip pembelajaran kontekstual yang harus dikembangkan oleh guru menurut Rusman (2012 ) antara lain: Komponen Pertama dilandasi Paham Kontruktivisme; merupakan landasan berpikir pembelajaran Pembelajaran kontekstual, yaitu bahwa pengetahuan dibangun oleh manusia sedikit demi sedikit yang hasilnya diperluas melalui konteks yang terbatas (sempit). Komponen Kedua, Melaksanakan Inkuiri, merupakan kegiatan inti dari pembelajaran kontekstual. Siklus inkuiri meliputi: (1) observasi; (2) bertanya; (3) mengajukan hipotesis; (4) pengumpulan data; (5) penyimpulan. Komponen Ketiga, Melakukan Questioning (Bertanya) salah satu prinsip pembelajaran kontekstual berfungsi bagi pendidik untuk mendorong, membimbing, dan menilai kemampuan berpikir peserta didik; sedangkan bagi peserta didik berfungsi untuk menggali informasi, mengkonfirmasikan apa yang sudah diketahui, serta mengarahkan perhatian pada aspek yang belum diketahui. Komponen Keempat, Melakukan Masyarakat Belajar (Belajar Kelompok) CTL menyarankan agar hasil pembelajaran diperoleh melalui kerjasama dengan orang lain. Komponen kelima, melakukan pemodelan (modelling) adalah memperagakan sesuatu sebagai contoh yang dapat ditiru oleh setiap siswa. Pemodelan diperlukan sebagai contoh untuk ditiru (diteladani) oleh peserta didik yang lain dalam hal-hal atau materi pembelajaran yang mengembangkan keterampilan motorik maupun kemampuan kognitif. Komponen Keenam, Melakukan Refleksi (Reflection) yaitu berpikir atau mengenang kembali hal-hal yang sudah dipelajari atau yang sudah dialami pada waktu yang lampau, sebagai respon terhadap kejadian atau aktivitas terhadap pengetahuan yang baru diterima. Komponen Ketujuh, Melakukan Penilaian Autentik (Authentic Assessment). Penilaian dimaksudkan untuk menilai pengetahuan dan keterampilan (performance) yang secara riil telah diperoleh oleh peserta didik dari proses pembelajaran yang telah berlangsung.

\section{Kecerdasan Intelektual (IQ)}

Wechsler seorang ilmuwan dari Amerika adalah orang yang membuat tes intelektual WAIS (The Wechsler Adult Intelligence Secale) yang banyak digunakan di seluruh dunia. Wechsler mengemukakan bahwa kecerdasan intelektual adalah kemampuan global yang dimiliki oleh individu agar bisa bertindak secara terarah dan berpikir secara bermakna serta bisa berinteraksi dengan lingkungan secara efisien. Kemampuan intelektual (inteligensi) ini dapat diukur dengan suatu alat tes yang biasa disebut IQ (Intelligence Quotient). IQ (Intelligence Quotient) adalah ekspresi dari tingkat kemampuan individu pada saat tertentu, dalam hubungan dengan norma usia yang ada. Pengukuran kecerdasan intelektual tidak dapat diukur hanya dengan satu pengukuran tunggal.

Para peneliti menemukan bahwa tes untuk mengukur kemampuan kognitif tersebut, yang utama adalah dengan menggunakan tiga pengukuran yaitu kemampuan verbal, kemampuan matematika, dan kemampuan ruang (Moustafa dan Miller, 2003).

\section{Kecerdasan Emosional (EQ)}

Kata emosi berasal dari bahasa latin, yaitu emovere yang berarti bergerak menjauh. Arti kata ini menyiratkan bahwa kecenderungan bertindak merupakan hal mutlak dalam emosi. Menurut Bradberry \& Luc (2006), emosi merujuk pada suatu perasaan dan pikiran yang khas, suatu keadaan 
biologis dan psikologis dan serangkaian kecenderungan untuk bertindak. Emosi berkaitan dengan perubahan fisiologis dan berbagai pikiran. Jadi, emosi merupakan salah satu aspek penting dalam kehidupan manusia, karena emosi dapat merupakan motivator perilaku dalam arti meningkatkan, tapi juga dapat mengganggu perilaku intensional manusia. Kecerdasan emosional sangat dipengaruhi oleh lingkungan, tidak bersifat menetap, dapat berubah-ubah setiap saat. Untuk itu peranan lingkungan terutama orang tua pada masa kanak-kanak sangat mempengaruhi dalam pembentukan kecerdasan emosional, karena kecerdasan emosional tidak dipengaruhi oleh faktor keturunan (Bradberry \& Luc, 2006).

Goleman (2009), mengungkapkan bahwa kecerdasan emosional merupakan kemampuan untuk menggunakan emosi secara efektif dalam mengelola diri sendiri dan mempengaruhi hubungan dengan orang lain secara positif. Menurut Goleman (2009), mengungkapkan kecerdasan emosional seseorang dapat diukur dari beberapa 5 aspek yaitu: (a) Mengenali emosi diri (self awareness); (b) Mengelola emosi (self management); (c) Memotivasi diri (motivation); (d) Mengenali emosi orang lain (social awareness); dan (e) Membina hubungan (relationship management).

\section{Kecerdasan Spritual (EQ)}

Zohar dan Marshal (2002) mendefinisikan kecerdasan spiritual sebagai rasa moral, kemampuan menyesuaikan aturan yang dibarengi dengan pemahaman dan cinta, kecerdasan yang menempatkan perilaku hidup kita dalam konteks makna yang lebih luas dan kaya, serta kecerdasan untuk menilai bahwa tindakan atau jalan hidup seseorang lebih bernilai dan bermakna. Istilah kecerdasan spiritual mulai muncul karena banyak orang yang memperdebatkan tentang kecerdasan intelektual dan kecerdasan emosional yang dipandang hanya menyumbang sebagian dari penentu kesuksesan seseorang dalam kehidupan.

Menurut Zohar dan Marshall (2007), indikator kecerdasan spiritual (SQ) tinggi yaitu: (a) Kemampuan bersikap fleksibel (adaptif secara spontan dan aktif); (b) Tingkat kesadaran tinggi; (c) Kemampuan mengadaptasi dan memanfaatkan penderitaan; (d) Kemampuan menghadapi dan melampaui rasa sakit; (e) Kualitas hidup yang diilhami oleh visi dan misi. (f) Keengganan untuk menyebabkan kerugian yang tidak perlu. (g) Kecenderungan untuk melihat keterkaitan antara berbagai hal (berpendangan holisitik). (h) Kecenderungan nyata untuk bertanya "mengapa atau bagaimana mencari jawaban dasar. Faktor kecerdasan spiritual lebih menekankan pada makna hidup dan bukan hanya terbatas pada penekanan agama saja Hoffman (2002). Bila spiritual quotient (SQ) telah berkembang dengan baik, maka gambaran atau ciri-ciri orang yang memiliki kecerdasan spiritual (SQ) tinggi

\section{METODE PENELITIAN}

Penelitian ini merupakan penelitian eksperimen semu; dengan desain "post-test only control group design". Rancangan analisis data yang digunakan dalam penelitian ini adalah rancangan analisis kovarian (ANACOVA) satu jalan-dua kovariabel. Penelitian dilakukan di Program studi Pendidikan Biologi, Universitas Kristen Artha Wacana Kupang pada semester genap tahun ajaran 2017/2018. Populasi adalah seluruh mahasiswa semester IV berjumlah 197 mahasiswa. Pengambilan sampel penelitian menggunakan teknik random sampling dan dipakai dua kelas sebagai kelas eksperimen dan dua kelas sebagai kelas kontrol dengan jumlah 70 mahasiswa. Tahapan pelaksanaan penelitian dilaksanakan sebagai berikut: (1) Tahapan Persiapan eksperimen meliputi: pembuatan silabus, RPS, instrument penelitian, melakukan uji coba instrumen, menguji validitas dan reliabiltas instrumen penelitian; (2) Tahapan pelaksanaan eksperimen; (3) Tahap pengumpulan data: meliputi tes IQ, angket EQ dan SQ pada kelas eksperimen dan kelas kontrol; dan (4) Tahapan Pengolahan data meliputi: uji prasyarat analisis, uji statistik deskriptif, uji hipotesis penelitian, dan penarikan kesimpulan. Teknik pengumpulan data adalah tes IQ, angket EQ, dan SQ. Teknik analisa data menggunakan dua teknik analisis yaitu analisis statistik deskriptif dan analisis inferensial yaitu analisis kovarian (anakova) satu jalan-dua kovariabel. Analisis statistik deskriptif dapat mendeskripsikan masing-masing variabel penelitian sedangkan analisis kovarian (anakova) dapat menguji hipotesis yang diajukan. 


\section{HASIL PENELITIAN DAN PEMBAHASAN}

Hasil perhitungan skor IQ, EQ dan SQ mahasiswa setelah pembelajaran kontekstual dan integrasi pendidikan karakter (kelas eksperimen) dan pembelajaran DI (kelas control) pada Prodi Pendidikan Biologi UKAW dapat dilihat pada Tabel 1

Tabel 1. Rekapitulasi Hasil Perhitungan Skor IQ, EQ, dan SQ Mahasiswa Prodi Pendidikan Biologi UKAW

\begin{tabular}{ccccccc}
\hline Data Statistik & $\mathbf{Y A}_{\mathbf{1}}$ & $\mathbf{Y A}_{\mathbf{2}}$ & $\mathbf{X}_{\mathbf{1}} \mathbf{A}_{\mathbf{1}}$ & $\mathbf{X}_{\mathbf{1}} \mathbf{A}_{\mathbf{2}}$ & $\mathbf{X}_{\mathbf{2}} \mathbf{A}_{\mathbf{1}}$ & $\mathbf{X}_{\mathbf{2}} \mathbf{A}_{\mathbf{2}}$ \\
\hline Mean & 65.88 & 54.35 & 118.95 & 116.35 & 91.18 & 93.93 \\
\hline Modus & 60 & 53 & 114 & 130 & 94 & 93 \\
\hline Median & 67 & 53 & 116.5 & 117 & 91.5 & 94 \\
\hline SD & 7.05 & 5.08 & 7.15 & 9.75 & 5.09 & 3.09 \\
\hline Variance & 49.75 & 25.82 & 51.18 & 95.05 & 25.94 & 9.56 \\
\hline Skor Min. & 47 & 45 & 104 & 93 & 79 & 87 \\
\hline Skor Maks. & 80 & 63 & 137 & 137 & 97 & 98 \\
\hline Rentangan & 33 & 18 & 33 & 44 & 18 & 11 \\
\hline
\end{tabular}

\section{Keterangan:}

$Y A_{1} \quad$ : kecerdasan intelektual (IQ) mahasiswa mengikuti pembelajaran kontekstual dengan integrasi pendidikan karakter.

$Y A_{2} \quad$ : kecerdasan intelektual (IQ) mahasiswa mengikuti pembelajaran DI

$X_{1} A_{1}$ : kecerdasan emosional (EQ) mahasiswa mengikuti pembelajaran kontekstual dengan integrasi pendidikan karakter.

$X_{1} A_{2}$ : kecerdasan emosional (EQ) mahasiswa mengikuti pembelajaran DI.

$X_{2} A_{1}$ : kecerdasan spritual (SQ) mahasiswa mengikuti pembelajaran kontekstual dengan integrasi pendidikan karakter.

$X_{2} A_{2}$ : kecerdasan spritual (SQ) mahasiswa mengikuti pembelajaran DI.

\section{Hasil Uji Hipotesis Pertama:}

Bunyi Hipotesis pertama yang diuji:

$\mathrm{H}_{0}$ : Terdapat perbedaan IQ antara mahasiswa yang mengikuti pembelajaran dengan mengintegrasi pendidikan karakter melalui pendekatan kontekstual dan pembelajaran DI

$\mathrm{H}_{\mathrm{a}}$ : Tidak terdapat perbedaan IQ antara mahasiswa yang mengikuti pembelajaran dengan mengintegrasi pendidikan karakter melalui pendekatan kontekstual dan pembelajaran DI.

Hasil uji hipotesis pertama sebagaimana terlihat pada Tabel 2 di bawah ini.

Tabel 2. Output SPSS Hasil Uji Hipotesis 1

$$
\text { Tests of Between-Subjects Effects }
$$

\begin{tabular}{lrrrrr}
\hline Dependent Variable: & IQ & & & & \\
\hline Source & Type III Sum of Squares & df & Mean Square & F & Sig. \\
\hline Corrected Model & $2622.394^{\text {a }}$ & 1 & 2622.394 & 67.992 & .000 \\
\hline Intercept & 289438.191 & 1 & 289438.191 & 7504.397 & .000 \\
\hline A & 2622.394 & 1 & 2622.394 & 67.992 & .000 \\
\hline Error & 3008.394 & 78 & 38.569 & & \\
\hline Total & 295068.978 & 80 & & & \\
\hline Corrected Total & 5630.787 & 79 & & & \\
\hline a. R Squared $=.466$ (Adjusted R Squared $=.459)$ \\
\hline
\end{tabular}

Berdasarkan hasil perhitungan diatas nilai $\mathrm{F}=67,992$ dengan signifikansi 0,000 artinya $\mathrm{H}_{0}$ ditolak dan $\mathrm{H}_{1}$ diterima. Jadi dapat dikatakan bahwa Terdapat perbedaan kemampuan kecerdasan intelektual (IQ) antara mahasiswa yang mengikuti pembelajaran dengan mengintegrasi pendidikan karakter melalui pendekatan kontekstual dan mahasiswa yang mengikuti pembelajaran direct instructional (DI). 


\section{Hasil Uji Hipotesis Kedua:}

Bunyi Hipotesis kedua yang diuji:

$\mathrm{H}_{0}$ : Setelah dikendalikan kovariabel EQ,tidak terdapat perbedaan IQ antara mahasiswa yang mengikuti pembelajaran dengan mengintegrasi pendidikan karakter melalui pendekatan kontekstual dan pembelajaran DI

$\mathrm{H}_{\mathrm{a}}$ : Setelah dikendalikan kovariabel EQ, terdapat perbedaan IQ antara mahasiswa yang mengikuti pembelajaran dengan mengintegrasi pendidikan karakter melalui pendekatan kontekstual dan pembelajaran DI

Hasil Uji hipotesis kedua, sebagaimana terlihat pada Tabel 3 di bawah ini:

Tabel 3. Hasil Output SPSS Uji Hipotesis 2

\section{Tests of Between-Subjects Effects}

Dependent Variable: IQ

\begin{tabular}{lrrrrr}
\hline Source & Type III Sum of Squares & df & Mean Square & F & Sig. \\
\hline Corrected Model & $2720.653^{\mathrm{a}}$ & 2 & 1360.326 & 35.993 & .000 \\
\hline Intercept & 2342.315 & 1 & 2342.315 & 61.976 & .000 \\
\hline $\mathrm{X} 1$ & 98.259 & 1 & 98.259 & 2.600 & .111 \\
\hline $\mathrm{A}$ & 2716.636 & 1 & 2716.636 & 71.880 & .000 \\
\hline Error & 2910.135 & 77 & 37.794 & & \\
\hline Total & 295068.978 & 80 & & & \\
\hline Corrected Total & 5630.787 & 79 & & & \\
\hline
\end{tabular}

a. R Squared $=.483$ (Adjusted R Squared $=.470$ )

Berdasarkan ringkasan analisis ANAKOVA satu jalan satu kovariabel yang disajikan pada tabel diatas diperoleh $\mathrm{F}=71,880$ dengan sig 0,000 artinya $\mathrm{H}_{0}$ ditolak dan $\mathrm{H}_{1}$ diterima. Jadi dapat dikatakan bahwa Setelah dikendalikan kovariabel kecerdasan emosional (EQ), terdapat perbedaan kemampuan kecerdasan intelektual (IQ) antara mahasiswa yang mengikuti pembelajaran dengan mengintegrasi pendidikan karakter melalui pendekatan kontekstual dan mahasiswa yang mengikuti pembelajaran direct instructional (DI).

\section{Hasil Uji Hipotesis Ketiga}

Bunyi Hipotesis ketiga yang diuji:

$\mathrm{H}_{0}$ : Setelah dikendalikan kovariabel SQ, tidak terdapat perbedaan IQ antara mahasiswa yang mengikuti pembelajaran dengan mengintegrasi pendidikan karakter melalui pendekatan kontekstual dan pembelajaran DI

$\mathrm{H}_{\mathrm{a}}$ : Setelah dikendalikan kovariabel SQ, terdapat perbedaan IQ antara mahasiswa yang mengikuti pembelajaran dengan mengintegrasi pendidikan karakter melalui pendekatan kontekstual dan pembelajaran DI

Hasil Uji hipotesis ketiga, sebagaimana terlihat pada Tabel 4 di bawah ini:

Tabel 4. Hasil Output SPSS Uji Hipotesis 3

\begin{tabular}{|c|c|c|c|c|c|}
\hline \multicolumn{6}{|c|}{ Tests of Between-Subjects Effects } \\
\hline \multicolumn{6}{|c|}{ Dependent Variable: IQ } \\
\hline Source & $\begin{array}{l}\text { Type III Sum of } \\
\text { Squares }\end{array}$ & df & Mean Square & $\mathrm{F}$ & Sig. \\
\hline Corrected Model & $2675.311^{\mathrm{a}}$ & 2 & 1337.655 & 34.850 & .000 \\
\hline Intercept & 285.325 & 1 & 285.325 & 7.434 & .008 \\
\hline $\mathrm{X} 2$ & 52.917 & 1 & 52.917 & 1.379 & .244 \\
\hline A & 2591.340 & 1 & 2591.340 & 67.513 & .000 \\
\hline Error & 2955.476 & 77 & 38.383 & & \\
\hline Total & 295068.978 & 80 & & & \\
\hline Corrected Total & 5630.787 & 79 & & & \\
\hline
\end{tabular}

a. $\mathrm{R}$ Squared $=.475$ (Adjusted R Squared $=.461$ ) 
Berdasarkan ringkasan analisis ANAKOVA satu jalur satu kovariabel yang disajikan pada tabel diatas diperoleh $\mathrm{F}=67,513$ dengan sig 0,000 , artinya $\mathrm{H}_{0}$ ditolak dan $\mathrm{H}_{1}$ diterima. Jadi dapat dikatakan bahwa setelah dikendalikan kovariabel kecerdasan spiritual (SQ), terdapat perbedaan kemampuan kecerdasan intelektual (IQ) antara mahasiswa yang mengikuti pembelajaran dengan mengintegrasi pendidikan karakter melalui pendekatan kontekstual dan mahasiswa yang mengikuti pembelajaran direct instructional (DI).

\section{Hasil Uji Hipotesis Keempat}

Bunyi Hipotesis keempat yang diuji:

$\mathrm{H}_{0}$ : Setelah dikendalikan kovariabel EQ dan SQ, tidak terdapat perbedaan IQ antara mahasiswa yang mengikuti pembelajaran dengan mengintegrasi pendidikan karakter melalui pendekatan kontekstual dan pembelajaran DI

$\mathrm{H}_{\mathrm{a}}$ : Setelah dikendalikan kovariabel EQ dan SQ, terdapat perbedaan IQ antara mahasiswa yang mengikuti pembelajaran dengan mengintegrasi pendidikan karakter melalui pendekatan kontekstual dan pembelajaran DI

Hasil uji hipotesis keempat, sebagaimana terlihat pada Tabel 5 di bawah ini.

Tabel 5 Hasil Output SPSS Uji Hipotesis 4

\begin{tabular}{|c|c|c|c|c|c|}
\hline \multicolumn{6}{|c|}{ Tests of Between-Subjects Effects } \\
\hline Dependent Variable: & IQ & & & & \\
\hline Source & $\begin{array}{c}\text { Type III Sum of } \\
\text { Squares }\end{array}$ & df & Mean Square & $\mathrm{F}$ & Sig. \\
\hline Corrected Model & $2788.863^{\mathrm{a}}$ & 3 & 929.621 & 24.860 & .000 \\
\hline Intercept & 396.738 & 1 & 396.738 & 10.610 & .002 \\
\hline $\mathrm{X} 2$ & 68.211 & 1 & 68.211 & 1.824 & .181 \\
\hline $\mathrm{X} 1$ & 113.553 & 1 & 113.553 & 3.037 & .085 \\
\hline A & 2702.262 & 1 & 2702.262 & 72.265 & .000 \\
\hline Error & 2841.924 & 76 & 37.394 & & \\
\hline Total & 295068.978 & 80 & & & \\
\hline Corrected Total & 5630.787 & 79 & & & \\
\hline
\end{tabular}

a. $\mathrm{R}$ Squared $=.495$ (Adjusted R Squared $=.475$ )

Berdasarkan ringkasan analisis ANAKOVA satu jalan dua kovariabel yang disajikan pada tabel diatas diperoleh $\mathrm{F}=72,265$ dengan sig 0,00 artinya $\mathrm{H}_{0}$ ditolak dan $\mathrm{H}_{1}$ diterima. Jadi dapat dikatakan bahwa setelah dikendalikan kovariabel kecerdasan emosional (EQ) dan kecerdasan spiritual (SQ), terdapat perbedaan kemampuan kecerdasan intelektual (IQ) antara mahasiswa yang mengikuti pembelajaran dengan mengintegrasi pendidikan karakter melalui pendekatan kontekstual dan mahasiswa yang mengikuti pembelajaran direct instructional (DI).

\section{Hasil hipotesis kelima}

Bunyi Hipotesis kelima yang diuji adalah:

$\mathrm{H}_{0}$ :Kecerdasan emosional (EQ) tidak berkontribusi secara signifikan terhadap kemampuan intelektual (IQ)

$\mathrm{H}_{\mathrm{a}}$ : Kecerdasan emosional (EQ) berkontribusi secara signifikan terhadap kemampuan intelektual (IQ)

Hasil uji hipotesis kelima sebagaimana terlihat pada Tabel 6 di bawah ini. 
Tabel 6. Hasil Output Uji Hipotesis 5

\begin{tabular}{|c|c|c|c|c|c|c|}
\hline \multicolumn{7}{|c|}{ ANOVA $^{\mathrm{a}}$} \\
\hline Model & & $\begin{array}{l}\text { Sum of } \\
\text { Squares }\end{array}$ & Df & Mean Square & $\mathrm{F}$ & Sig. \\
\hline \multirow{3}{*}{1} & Regression & 4.017 & 1 & 4.017 & .056 & $.814^{\mathrm{b}}$ \\
\hline & Residual & 5626.770 & 78 & 72.138 & & \\
\hline & Total & 5630.787 & 79 & & & \\
\hline \multicolumn{7}{|c|}{ a. Dependent Variable: IQ } \\
\hline \multicolumn{7}{|c|}{ b. Predictors: (Constant), EQ } \\
\hline
\end{tabular}

Model Summary

\begin{tabular}{|c|c|c|c|c|c|c|c|c|c|}
\hline \multirow[t]{2}{*}{ Model } & \multirow[t]{2}{*}{$\mathrm{R}$} & \multirow{2}{*}{$\begin{array}{c}\mathrm{R} \\
\text { Square }\end{array}$} & \multirow{2}{*}{$\begin{array}{l}\text { Adjusted } \\
\text { R Square }\end{array}$} & Std. Error & \multicolumn{5}{|c|}{ Change Statistics } \\
\hline & & & & $\begin{array}{c}\text { of the } \\
\text { Estimate }\end{array}$ & $\begin{array}{l}\text { R Square } \\
\text { Change }\end{array}$ & $\begin{array}{c}\mathrm{F} \\
\text { Change }\end{array}$ & df1 & df2 & $\begin{array}{l}\text { Sig. F } \\
\text { Change }\end{array}$ \\
\hline 1 & $.027^{\mathrm{a}}$ & .001 & -.012 & 8.493 & .001 & .056 & & 78 & .814 \\
\hline
\end{tabular}

Nilai $F=0,056$ dengan sig. 0,814 pada taraf signifikansi 0,05 , berarti hipotesis nol diterima dan hipotesis alternatif ditolak, sehingga harga F regresi adalah tidak signifikan. Dengan demikian tidak terdapat hubungan fungsional yang signifikan antara variabel EQ dan IQ.

Untuk mengetahui kontribusi variabel prediktor terhadap kriterium, nilai koefisien korelasinya dikuadratkan sehingga diperoleh nilai R sebesar 8,49\%; ini berarti sumbangan atau kontribusi variabel EQ mahasiswa terhadap IQ mahasiswa adalah sebesar 8,49\% sedangkan residunya 91,51\% dijelaskan oleh variabel lain yang tidak termasuk dalam penelitian ini.

\section{Hasil Uji Hipotesis Keenam}

Bunyi hipotesis ke enam yang diuji adalah:

$\mathrm{H}_{0}$ : Kecerdasan spiritual (SQ) tidak berkontribusi secara signifikan terhadap kemampuan intelektual (IQ)

$\mathrm{H}_{\mathrm{a}}$ : Kecerdasan spiritual (SQ) berkontribusi secara signifikan terhadap kemampuan intelektual (IQ)

Hasil uji hipotesis keenam sebagaimana terlihat pada tabel 7 di bawah ini.

Tabel 7. Hasil Pengujian Hipotesis Keenam dengan SPSS 20 for windows

\begin{tabular}{llrrrrr}
\hline \multicolumn{7}{c}{ ANOVA $^{\mathbf{a}}$} \\
\hline Model & & Sum of Squares & df & Mean Square & F & Sig. \\
\hline \multirow{2}{*}{1} & Regression & 83.971 & 1 & 83.971 & 1.181 & $.281^{\text {b }}$ \\
& Residual & 5546.816 & 78 & 71.113 & & \\
& Total & 5630.787 & 79 & & & \\
\hline
\end{tabular}

a. Dependent Variable: IQ

b. Predictors: (Constant), SQ

Model Summary ${ }^{\mathrm{b}}$

\begin{tabular}{|c|c|c|c|c|c|c|c|c|c|}
\hline \multirow[t]{2}{*}{ Model } & \multirow[t]{2}{*}{$\mathrm{R}$} & \multirow{2}{*}{$\begin{array}{c}\mathrm{R} \\
\text { Square }\end{array}$} & \multirow{2}{*}{$\begin{array}{l}\text { Adjusted } \\
\text { R Square }\end{array}$} & \multirow{2}{*}{$\begin{array}{l}\text { Std. Error } \\
\text { of the } \\
\text { Estimate }\end{array}$} & \multicolumn{5}{|c|}{ Change Statistics } \\
\hline & & & & & $\begin{array}{c}\text { R Square } \\
\text { Change }\end{array}$ & $\begin{array}{c}\mathrm{F} \\
\text { Change }\end{array}$ & df1 & df 2 & $\begin{array}{l}\text { Sig. F } \\
\text { Change }\end{array}$ \\
\hline 1 & $.122^{\mathrm{a}}$ & .015 & .002 & 8.433 & .015 & 1.181 & 1 & 78 & .281 \\
\hline
\end{tabular}

Nilai $F=1,181$ dengan sig. 0,218 pada taraf signifikansi 0,05 , berarti hipotesis nol diterima dan hipotesis alternatif ditolak, sehingga harga $\mathrm{F}$ regresi adalah tidak signifikan. Dengan demikian tidak terdapat hubungan fungsional yang signifikan antara variabel SQ dan IQ. Untuk mengetahui kontribusi 
variabel prediktor terhadap kriterium, nilai koefisien korelasinya dikuadratkan sehingga diperoleh nilai R sebesar 8,43 \%; ini berarti sumbangan atau kontribusi variabel SQ mahasiswa terhadap IQ mahasiswa adalah sebesar $8,43 \%$ sedangkan residunya $91,57 \%$ dijelaskan oleh variabel lain yang tidak termasuk dalam penelitian ini.

\section{Hasil Uji Hipotesis Ketujuh}

Bunyi hipotesis ketujuh yang diuji adalah:

$\mathrm{H}_{0}$ : Kecerdasan emosional (EQ) dan kecerdasan spiritual (SQ) bersama-sama tidak berkontribusi secara signifikan terhadap kecerdasan intelektual (IQ).

$\mathrm{H}_{\mathrm{a}}$ : Kecerdasan emosional (EQ) dan kecerdasan spiritual (SQ) bersama-sama berkontribusi secara signifikan terhadap kecerdasan intelektual (IQ).

Hasil uji hipotesis ketujuh adalah sebagaimana terlihat pada tabel 8 di bawah ini.

Tabel 8. Hasil Output SPSS Uji Hipotesis 7

\begin{tabular}{|c|c|c|c|c|c|c|}
\hline \multicolumn{7}{|c|}{ ANOVA $^{a}$} \\
\hline Model & & $\begin{array}{l}\text { Sum of } \\
\text { Squares }\end{array}$ & df & Mean Square & $\mathrm{F}$ & Sig. \\
\hline \multirow{3}{*}{1} & Regression & 86.601 & 2 & 43.301 & .601 & $.551^{\mathrm{b}}$ \\
\hline & Residual & 5544.186 & 77 & 72.002 & & \\
\hline & Total & 5630.787 & 79 & & & \\
\hline \multicolumn{7}{|c|}{ a. Dependent Variable: IQ } \\
\hline \multicolumn{7}{|c|}{ b. Predictors: (Constant), EQ, SQ } \\
\hline
\end{tabular}

Model Summary

\begin{tabular}{|c|c|c|c|c|c|c|c|c|c|}
\hline \multirow[t]{2}{*}{ Model } & \multirow[t]{2}{*}{$\mathrm{R}$} & \multirow{2}{*}{$\begin{array}{c}\mathrm{R} \\
\text { Square }\end{array}$} & \multirow{2}{*}{$\begin{array}{l}\text { Adjusted } \\
\text { R Square }\end{array}$} & \multirow{2}{*}{$\begin{array}{l}\text { Std. Error } \\
\text { of the } \\
\text { Estimate }\end{array}$} & \multicolumn{5}{|c|}{ Change Statistics } \\
\hline & & & & & $\begin{array}{l}\text { R Square } \\
\text { Change }\end{array}$ & $\begin{array}{c}\mathrm{F} \\
\text { Change }\end{array}$ & df1 & df 2 & $\begin{array}{c}\text { Sig. F } \\
\text { Change }\end{array}$ \\
\hline 1 & $.124^{\mathrm{a}}$ & .015 & -.010 & 8.485 & .015 & .601 & 2 & 77 & .551 \\
\hline \multicolumn{10}{|c|}{ a. Predictors: (Constant), EQ, SQ } \\
\hline b. Depe & lent $\mathrm{Va}$ & ariable: I & & & & & & & \\
\hline
\end{tabular}

Nilai $F=0,601$ dengan sig. 0,551 pada taraf signifikansi 0,05 , berarti hipotesis nol diterima dan hipotesis alternatif ditolak, sehingga harga $\mathrm{F}$ regresi adalah tidak signifikan. Dengan demikian tidak terdapat hubungan fungsional yang signifikan antara variabel EQ, SQ dan IQ.

Untuk mengetahui kontribusi variabel prediktor terhadap kriterium, nilai koefisien korelasinya dikuadratkan sehingga diperoleh nilai R sebesar 8,48 \%; ini berarti sumbangan atau kontribusi variabel EQ dan SQ mahasiswa terhadap IQ mahasiswa adalah sebesar 8,48\% sedangkan residunya 91,52\% dijelaskan oleh variabel lain yang tidak termasuk dalam penelitian ini.

\section{Pembahasan}

Penelitian yang dilaksanakan berupa implementasi Pendidikan karakter di perguruan tinggi yang terpadu dengan kegiatan pembelajaran pada mata kuliah Profesi Pendidikan. Nilai-nilai karakter direncanakan dalam Rencana Pembelajaran Semester (RPS) dan diimplementasi dalam kegiatan perkuliahan melalui pendekatan kontekstual. Integrasi pendidikan karakter dalam pembelajaran mata kuliah Profesi Pendidikan mengambil 8 dari 18 nilai-nilai karakter menurut Pusat Kurikulum Depdiknas (2010) yaitu: religius, jujur, disiplin, kreatif, rasa ingin tahu, komunikatif, peduli social, dan tanggungjawab. Implementasi nilai-nilai karakter tersebut dilakukan secara terpadu dalam kegiatan pembelajaran yang berlangsung dalam kelas.

Proses pembelajaran dalam kelas Eksperimen (mengintegrasi pendidikan karakter dan penerapan pendekatan kontekstual) dilakukan dengan langkah-langkah pembelajaran yang sesuai dengan pendapat dari Rusman (2012) yaitu: konstruktivisme dimana siswa mengkonstruksi pengetahuan sendiri, melaksanakan Inkuiri melalui proses diskusi kelompok meliputi kegiatan observasi; bertanya; mengajukan hipotesis, pengumpulan data dan penyimpulan. Kegiatan bertanya melalui proses diskusi dan presentasi kelompok. Melakukan Masyarakat Belajar (Belajar Kelompok) 
CTL menyarankan agar hasil pembelajaran diperoleh melalui kerjasama dengan orang lain. Komponen kelima, melakukan pemodelan (modelling) adalah memperagakan sesuatu sebagai contoh yang dapat ditiru oleh setiap siswa. Pemodelan diperlukan sebagai contoh untuk ditiru (diteladani) oleh peserta didik yang lain dalam hal-hal atau materi pembelajaran yang mengembangkan keterampilan motorik maupun kemampuan kognitif. Komponen Keenam, Melakukan Refleksi (Reflection) yaitu berpikir atau mengenang kembali hal-hal yang sudah dipelajari atau yang sudah dialami pada waktu yang lampau, sebagai respon terhadap kejadian atau aktivitas terhadap pengetahuan yang baru diterima. Komponen Ketujuh, Melakukan Penilaian Autentik (Authentic Assessment). Penilaian dimaksudkan untuk menilai pengetahuan dan keterampilan (performance) yang secara riil telah diperoleh oleh peserta didik dari proses pembelajaran yang telah berlangsung.

Pelaksanaan pendidikan karakter dalam kegiatan pembelajaran diperlukan oleh karena melihat gambaran situasi dunia pendidikan di Indonesia menjadi motivasi pokok untuk mengimplementasikan pendidikan karakter.

Pengukuran kecerdasan intelektual (IQ) dilakukan berdasar pada pendapat Moustafa dan Miller (2003) dengan menggunakan tiga pengukuran yaitu kemampuan verbal, kemampuan matematika, dan kemampuan ruang. Pengukuran kecerdasan emosional (EQ) sejalan dengan pendapat Goleman (2009) yaitu: kecerdasan emosional seseorang dapat diukur dari beberapa 5 aspek yaitu: (a) Mengenali emosi diri (self awareness); (b) Mengelola emosi (self management); (c) Memotivasi diri (motivation); (d) Mengenali emosi orang lain (social awareness); dan (e) Membina hubungan (relationship management). Pengukuran kecerdasan spiritual berdasar pada pendapat Zohar dan Marshall (2007) yaitu: (a) Kemampuan bersikap fleksibel (adaptif secara spontan dan aktif); (b) Tingkat kesadaran tinggi; (c) Kemampuan mengadaptasi dan memanfaatkan penderitaan; (d) Kemampuan menghadapi dan melampaui rasa sakit; (e) Kualitas hidup yang diilhami oleh visi dan misi. (f) Keengganan untuk menyebabkan kerugian yang tidak perlu. (g) Kecenderungan untuk melihat keterkaitan antara berbagai hal (berpendangan holisitik). (h) Kecenderungan nyata untuk bertanya "mengapa atau bagaimana mencari jawaban dasar.

Berdasarkan hasil uji hipotesis penelitian pertama, kedua, ketiga dan keempat dapat dijelaskan bahwa kegiatan pembelajaran untuk mata kuliah Profesi Pendidikan menggunakan pendekatan kontekstual bagi mahasiswa Prodi Pendidikan Biologi UKAW memberikan pengaruh terhadap kecerdasan intelektual (IQ), Kecerdasan emosional (EQ) dan kecerdasan spiritual (SQ). Hasil penelitian sejalan dengan pendapat Rusman (2012) yang menyatakan pembelajaran kontekstual (contextual teaching and learning) merupakan konsep belajar yang dapat membantu guru mengaitkan antara materi yang diajarkannya sebagai situasi dunia nyata siswa dan mendorong siswa membuat hubungan antara pengetahuan yang dimilikinya dengan penerapan dalam kehidupan mereka sebagai anggota keluarga dan masyarakat. Pembelajaran kontekstual efektif karena diasumsikan bahwa proses pembelajaran akan benar-benar terjadi jika siswa dapat menemukan hubungan yang bermakna antara berpikir abstrak dengan aplikasi nyata dalam kehidupan.

Selain pengaruh dari pendekatan kontekstual, lebih lanjut pendapat Marten (2004) mengusulkan strategi pembelajaran karakter yang efektif, yakni harus dilakukan secara lebih konkret dilakukan melalui tiga tahapan yang perlu dilakukan dalam pembelajaran karakter, yakni: (1) identifikasi nilai, (2) pembelajaran nilai, dan (3) memberikan kesempatan untuk menerapkan nilai tersebut.

Pelaksanaan proses perkuliahan mata kuliah Profesi Pendidikan bagi mahasiswa Prodi Pendidikan Biologi UKAW kelas eksperimen menggunakan pendekatan kontekstual, dengan mengintegrasi nilai-nilai karakter seperti religius, disiplin, rasa ingin tahu, tanggung jawab, komunikatif dan kreatif. Pembiasaan karakter religious dilakukan pada saat perkuliahan diawali dengan berdoa. Pembiasaan nilai karakter disiplin dilakukan dengan mengecek kehadiran mahasiswa diawal perkuliahan. Pembiasaan nilai karakter rasa ingin tahu dilakukan pada saat proses diskusi dimana mahasiswa berusaha mencari dan menemukan pengetahuan. Hal ini berkaitan dengan pendekatan kontekstual komponen inkuiri. Pembiasaan nilai karakter tanggungjawab dilakukan pada saat mahasiswa berdisikusi dengan temannya. Mahasiswa diarahkan untuk memilki rasa tanggungjawab untuk bersama-sama menyelesaikan tugas diskusi yang diberikan. Pembiasaan nilai karakter komunikatif dilakukan melalui kegiatan presentasi hasil diskusi di depan mahasiswa-mahasiswa lain. Pembiasaan nilai karakter kreatif dilakukan dengan memberikan keluasan kepada mahasiswa untuk bekerja dan menyelesaikan tugas sesuai dengan kreatifitas mereka. 
Integrasi Pendidikan Karakter Melalui Pendekatan Kontekstual Dalam Mata Kuliah Profesi

Pendidikan Terhadap IQ Dengan Mengendalikan EQ dan SQ Mahasiswa (T. S. N. Manu, A. M. Meha)

Proses perkuliahan dengan mengintegrasi nilai-nilai karakter ini berlangsung selama beberapa pertemuan untuk memupuk dan membiasakan nilai-nilai karakter dalam diri mahasiswa. Hal di atas sejalan dengan pendapat Handoyo dan Tijan (2011) bahwa kegiatan pendidikan karakter di Perguruan Tinggi dapat dilakukan melalui berbagai bentuk aktivitas dan pengalaman belajar konkret, praktis dan memberikan pengalaman langsung kepada mahasiswa.

Pembelajaran yang mengintegrasi nilai-nilai karakter wajib diimplementasi kepada seluruh siswa di semua jenjang pendidikan. Pembelajaran mata kuliah Profesi Pendidikan harus diarahkan pada penanaman nilai karakter dengan melihat variabel-variabel yang turut mempengaruhi seperti IQ, EQ dan SQ.

Salah satu penelitian yang dilakukan oleh Supriyono, dkk (2018) menemukan bahwa cara penanaman nilai-nilai karakter dalam proses pembelajaran dapat dilakukan melalui memberikan tugas kepada siswa dan mereka menganalisis makna atau maksud yang terkandung. Dari sini terciptalah alur pembelajaran yang menyenangkan karena siswa diberikan kesempatan untuk dapat mengeksplorasi pengetahuan dan pengalaman yang dimiliki dan guru bertindak sebagai fasilitator yang mengarahkan mereka untuk dapat memahami nilai-nilai karakter yang terkandung sekaligusnya menerapkannya dalam proses diskusi.

Menurut Sweeney dan Cromley (2002) pembelajaran orang dewasa dapat berlangsung dengan efektif apabila menggunakan prinsip-prinsip pembelajaran aktif, strategi/pendekatan yang mendorong keterlibatan peseta didik. Pendekatan kontekstual merupakan salah satu pendekatan yang mampu membuat peserta didik aktif dalam kegiatan pembelajaran. Dalam proses pembelajaran, peserta didik membangun sendiri pengetahuan mereka melalui keterlibatan aktif dalam proses pembelajaran dan menjadi pusat kegiatan pembelajaran. Penerapan teori belajar konstruktivisme dalam pembelajaran dapat mengembangkan berbagai karakter, antara lain berfikir kritis dan logis, mandiri, rasa ingin tahu, menghargai orang lain, bertanggung jawab, dan percaya diri.

Selain itu, hasil penelitian Tanir \& Al Hroub (2013) menemukan bahwa pelaksanaan pendidikan karakter telah memberi manfaat bagi siswa yang memiliki kecerdasan intelektual lebih daripada siswa yang kurang mampu secara intelektual. Penting untuk dicatat bahwa pengaruh ini mungkin karena siswa tidak dapat mempertahankan atau meningkatkan kepercayaan diri mereka. Ada aspek positif dari hal ini, yang merupakan peningkatan kepercayaan diri bagi siswa yang menerima pendidikan karakter. Ini menunjukkan bahwa penelitian yang lebih mendalam harus dilakukan untuk memeriksa tujuan spesifik tersebut.

Hasil uji hipotesis kelima, keenam dan ketujuh dapat dijelaskan bahwa dalam pembelajaran Profesi pendidikan ketika pendidikan karakter diintegrasi dalam pembelajaran melalui pendekatan kontekstual ternyata memperoleh hasil tidak ada pengaruh dan kontribusi antara variabel EQ dengan IQ, SQ dan IQ serta EQ, dan SQ dengan IQ. Dapat dikatakan bahwa variabel IQ, EQ dan SQ memberikan kontribusi yang kecil untuk proses pembelajaran dalam mata kuliah profesi pendidikan. Hal ini dikarena terdapat faktor-faktor atau variabel-variabel lain luar yang turut mempengaruhi.

Selain itu, nilai kontribusi variabel EQ mahasiswa terhadap IQ mahasiswa adalah sebesar 8,49\%, kontribusi variabel SQ mahasiswa terhadap IQ mahasiswa adalah sebesar 8,43\% sedangkan kontribusi variabel EQ dan SQ terhadap IQ mahasiswa adalah sebesar 8,48\%. Nilai kontribusi untuk masing-masing variabel baik EQ, SQ, EQ dan SQ kurang dari $10 \%$. Oleh karena minimnya kontribusi variabel di atas, maka perlu diadakan penelitian lanjutan yang lebih mendalam untuk mengukur variabel lain misalnya: kepercayaan diri, minat, motivasi, perhatian, dan lain sebagainya.

\section{SIMPULAN DAN SARAN}

Berdasarkan hasil penelitian dapat disimpulkan:

1. Terdapat perbedaan kemampuan IQ antara mahasiswa yang mengikuti pembelajaran dengan mengintegrasi pendidikan karakter melalui pendekatan kontekstual dan mahasiswa yang mengikuti pembelajaran direct instructional (DI) dilihat dari nilai $\mathrm{F}=67,992$ dengan sig. 0,000.

2. Setelah dikendalikan kovariabel EQ, terdapat perbedaan kemampuan IQ antara mahasiswa yang mengikuti pembelajaran dengan mengintegrasi pendidikan karakter melalui pendekatan kontekstual dan mahasiswa yang mengikuti pembelajaran direct instructional (DI) dilihat dari nilai $\mathrm{F}=71,820$, sig. 0,000 ; 
3. Setelah dikendalikan kovariabel SQ terdapat perbedaan kemampuan IQ antara mahasiswa yang mengikuti pembelajaran dengan mengintegrasi pendidikan karakter melalui pendekatan kontekstual dan mahasiswa yang mengikuti pembelajaran direct instructional (DI dilihat dari nilai $\mathrm{F}=67,513$ sig. 0,000 ;

4. Setelah dikendalikan kovariabel EQ dan SQ terdapat perbedaan kemampuan IQ antara mahasiswa yang mengikuti pembelajaran dengan mengintegrasi pendidikan karakter melalui pendekatan kontekstual dan mahasiswa yang mengikuti pembelajaran direct instructional (DI) dilihat dari nilai $\mathrm{F}=72,265$ sig. 0,000 ;

5. EQ tidak berkontribusi secara signifikan terhadap IQ); dilihat dari niai $F=0,056$ sig. 0,814 dengan besar kontribusi 8,49\%

6. SQ tidak berkontribusi secara signifikan terhadap IQ; dilihat dari niai $F=1,181$ sig. 0,218 dengan besar kontribusi $8,43 \%$

7. EQ dan SQ bersama-sama tidak berkontribusi secara signifikan terhadap IQ dilihat dari nilai $\mathrm{F}=$ 1,181 sig. 0,218 dengan besar kontribusi 8,498\%

Saran dari hasil penelitian yang dapat diberikan:

1. Bagi pendidik: dapat menerapkan pendekatan kontektual dan mengimplementasikan nilai-nilai karakter dalam kegiatan pembelajaran.

2. Bagi peserta didik, perlu lebih memupuk nilai-nilai karakter dalam lingkungan kampus melalui keterlibatan dalam berbagai kegiatan.

3. Bagi peneliti lain, perlu melakukan penelitian lanjutan diluar variabel penelitian yang telah dilakukan sebagai upaya untuk meningkatkan IQ, EQ, dan SQ yang turut memberikan pengaruh bagi mutu pendidikan Indonesia misalnya: motivasi, minat, kepercayaan diri, dan lain sebagainya.

\section{UCAPAN TERIMAKASIH}

Ucapan terimakasih diberikan kepada: (1) DRPM Ditjen Penguatan Risbang, atas bantuan dana hibah Penelitian Dosen Pemula tahun 2018 yang diberikan kepada peneliti sehingga penelitian ini dapat berjalan dengan baik; (2) Program Studi Pendidikan Biologi UKAW Kupang atas bantuan dan kerjasama dalam pelaksanaan penelitian.

\section{DAFTAR PUSTAKA}

Aisyah.AR. (2014). Pemberian Layanan Pendidikan Karakter Di Perguruan Tinggi Dalam Meningkatkan Lulusan Berahlak Mulia. http://eprints.unsri.ac.id/3553/1/IMPLEMENTASI_PENDIDIKAN_KARAKTER_DALAM_ MANAJEMEN_SEKOLAH diakses tanggal 21 April 2018

Aunillah, Nuria Isna, 2011. Panduan Menerapkan Pendidikan Karakter di Sekolah. Jogjakarta: Laksana.

Bradberry, T. R \& Luc, D.S. 2006. Ability versus skill-based assessment of emotional intelligence. Psicothema, Vol. 18, pp 59-66.

Goleman, D. 2005. Emotional Intelligence (terjemahan: Alex Tri Kanjono Widodo). Jakarta: PT Gramedia Pustaka Utama.

Handoyo, Eko dan Tijan, 2010, Model Pendidikan Karakter Berbasis Konservasi: Pengalaman Universitas Negri Semarang, Semarang, Universitas Negri Semarang dan Widya Karya.

Kemendiknas. 2011. Panduan Pendidikan Karakter. Jakarta: Pusat Kurikulum dan Kebukuan Kemendiknas

Marten, R. (2004). Successful Coaching (Edisi ketiga). Champaign, IL: Human Kinetics

Moustafa, K,S, and, Miller, T, R, 2003, Too Intelligent For The Job? The Validity of Upper-Limit Cognitive Ability Test Scores In Selection, Sam Advanced Management Journal, Vol.68. 
Integrasi Pendidikan Karakter Melalui Pendekatan Kontekstual Dalam Mata Kuliah Profesi

Pendidikan Terhadap IQ Dengan Mengendalikan EQ dan SQ Mahasiswa (T. S. N. Manu, A. M. Meha)

Pusat Kurikulum Depdiknas. 2010. Bahan Pelatihan Penguatan Metodologi Pembelajaran Berdasarkan Nilai-nilai Budaya untuk Membentuk Daya Saing dan Karakter Bangsa. Jakarta: Kemendiknas.

Rusman. 2012. Model-Model Pembelajaran (mengembangkan profesionalisme guru). Jakarta: PT RajaGrafindo Persada.

Supriyono, S, Wardani, Nugraheni, Saddhono, Kundharu. 2018. Nilai Pendidikan Karakter Sajak "Bulan Ruwah" Karya Subagio Sastrowardoyo dalam Pembelajaran Sastra. Jurnal Scholaria: Jurnal Pendidikan dan Kebudayaan: Vol 8, No 2, Mei 2018: 120-131

Sweeney, T and Cromley, J. 2002. Adult Learners: Teaching Strategies ti Saiful Ridlo, Andin Irsadi Pengembangan Nilai Karakter Konservasi 154 Improve Learning and Comprehension. [Versi elektronik]. RMC Research

Tanir \& Al Hroub (2013). Effects of character education on the self-esteem of intellectually able and less able elementary students in Kuwait. International Journal Of Special Education. Vol 28, no: 2 .

Tikollah, M. Ridwan, I. Triyuwono, dan H. U. Ludigdo. 2006. Pengaruh Kecerdasan Intelektual, Kecerdasan Emosional, dan Kecerdasan Spiritual Terhadap Sikap Etis Mahasiswa Akuntansi (Studi pada Perguruan Tinggi Negeri di Kota Makassar Provinsi Sulawesi Selatan). Simposium Nasional Akuntansi 9, Hal.1-25.

Zohar, D. Marshall, I. 2007. SQ: Kecerdasan Spiritual. Bandung: Mizan. 